\title{
Self-assembly of a 2-D barium/thiodiacetate coordination polymer in aqueous solution
}

\author{
RIYA MUKHERJEE $\uparrow$, SCOTT D. BUNGE† and NICOLA E. BRASCH*†t \\ $\dagger$ Department of Chemistry, Kent State University, Kent, OH 44242, USA \\ †School of Biomedical Sciences, Kent State University, Kent, OH 44242, USA
}

(Received 10 February 2010; in final form 29 April 2010)

\begin{abstract}
A polymeric thiodiacetate (tda) complex of $\mathrm{Ba}^{2+},\left\{\mathrm{Ba}\left[\mathrm{S}\left(\mathrm{CH}_{2} \mathrm{COO}\right)_{2}\left(\mathrm{H}_{2} \mathrm{O}\right)_{3}\right] \cdot 2 \mathrm{H}_{2} \mathrm{O}\right\}_{n}$, has been synthesized from aqueous solution in $\sim 50 \%$ yield. The complex crystallizes in the monoclinic $P 2_{1} / c$ space group with $Z=4$ and the unit cell dimensions $a=13.069 \AA, b=7.350 \AA$, and $c=12.932 \AA$. $\mathrm{Ba}^{2+}$ is ten-coordinate, ligated to four tda $(\mathrm{O}$ and $\mathrm{S})$ and three aqua ligands. Four distinct binding modes of tda to barium are observed. Each $\mathrm{Ba}^{2+}$ center is coordinated via a tda ligand to four equivalent adjacent $\mathrm{Ba}^{2+}$ centers, creating an extended 2-D polymeric layered structure, with alternate interstitial layers of water. The complex has also been characterized by elemental analysis, FT-IR spectroscopy, and thermogravimetric analysis. ${ }^{1} \mathrm{H}$ and ${ }^{13} \mathrm{C}$ NMR spectroscopic data suggest that the polymeric structure found in the solid state is not present in aqueous solution itself.
\end{abstract}

Keywords: Barium; Thiodiacetate; Coordination polymer

\section{Introduction}

Metal-organic-based polymers have applications in catalysis, selective gas adsorption $\left(\mathrm{O}_{2}, \mathrm{~N}_{2}, \mathrm{H}_{2}\right.$, and methane) as ion-selective sensors and materials with interesting magnetic properties [1-3]. Di- and polycarboxylate ligands in particular have shown to be useful synthetic building blocks for metal-organic-based coordination polymers [2-4]. For example, coordination polymers of transition, alkaline earth, and lanthanide metals with oxydiacetate (oda, $\mathrm{O}\left(\mathrm{CH}_{3} \mathrm{COO}\right)_{2}^{2-}$ ) and thiodiacetate (tda, $\mathrm{S}\left(\mathrm{CH}_{3} \mathrm{COO}\right)_{2}^{2-}$ ) spontaneously self-assemble in aqueous solution [5-12]. Furthermore, the aqua ligands of $\mathrm{M}^{n+} / \mathrm{X}\left(\mathrm{CH}_{3} \mathrm{COO}\right)_{2}$ coordination polymers $(\mathrm{X}=\mathrm{O}$ or $\mathrm{S})$ are labile, resulting in a rich substitution chemistry [5, 6, 13].

Barium forms eight to twelve-coordinate complexes [14, 15] and is therefore an interesting choice of metal for metal-organic-based polymers, which have typically incorporated metal centers with octahedral geometries. Recently the first oda coordination polymers of $\mathrm{Ba}^{2+}$ were reported, with nine and ten-coordinate $\mathrm{Ba}^{2+}$ [10]. We report the synthesis and structural characterization of the first barium complex

*Corresponding author. Email: nbrasch@kent.edu 
of tda. Upon addition of 1.02 mole equivalents of tda ( $\mathrm{pH} 4.46)$ to an aqueous solution of $\mathrm{BaCl}_{2}$, a 2-D coordination polymer crystallizes from solution.

\section{Experimental}

All starting materials were of AR grade and used without further purification. Water was purified using a Barnstead Nanopure Diamond water purification system or HPLC-grade water was used. All $\mathrm{pH}$ measurements were made at room temperature with an Orion Model 710A pH meter equipped with Mettler-Toledo Inlab 423 or 421 electrodes. The electrode was filled with $3 \mathrm{~mol} \mathrm{~L}^{-1} \mathrm{KCl} /$ saturated $\mathrm{AgCl}$ solution, $\mathrm{pH}$ 7.0. The electrodes were standardized with standard $\mathrm{BDH}$ buffer solutions at $\mathrm{pH}$ 4.01 and 6.98. Solution $\mathrm{pH}$ was adjusted using $\mathrm{HCl}$ or $\mathrm{NaOH}$ solutions as necessary.

${ }^{1} \mathrm{H}$ NMR and ${ }^{13} \mathrm{C}$ NMR spectra were recorded on a Bruker $400 \mathrm{MHz}$ spectrometer equipped with a $5 \mathrm{~mm}$ probe at room temperature $\left(22 \pm 1^{\circ} \mathrm{C}\right)$. Solutions were prepared in $\mathrm{D}_{2} \mathrm{O}$ and 3-(trimethylsilyl)propionic-2,2,3,3- $\mathrm{d}_{4}$ acid (TSP, sodium salt) was used as an internal standard ( ${ }^{1} \mathrm{H}$ NMR).

Elemental analyses were carried out using a Leco CHNS-932 Elemental Analyzer (C and $\mathrm{H}$ ). Ba analysis was carried out using a ICP-AAS instrument at the Microanalytical Unit, Research School of Chemistry, Australian National University.

Electrospray-mass spectra (ES-MS) were recorded on a Thermo-Finnigan LCQDuo ion trap mass spectrometer at the mass spectrometry facility in the Department of Chemistry, Colorado State University.

FT-IR spectra were recorded using a Bruker Tensor 27 Infrared Spectrophotometer. Samples were prepared by grinding with $\mathrm{KBr}$ using mortar and pestle and crushed in a mechanical die press to form translucent pellets.

Thermogravimetric analysis (TGA) was performed on a TA Instruments Hi-Res TGA 2950 Thermogravimetric Analyzer using a high-resolution program under the flow of nitrogen at a heating rate of $5^{\circ} \mathrm{C} \mathrm{min}^{-1}$ from $21^{\circ} \mathrm{C}$ to $1000^{\circ} \mathrm{C}$.

\subsection{Synthesis of $\left\{\mathrm{Ba}\left[\mathrm{S}\left(\mathrm{CH}_{2} \mathrm{COO}\right)_{2}\left(\mathrm{H}_{2} \mathrm{O}\right)_{3}\right] \cdot 2 \mathrm{H}_{2} \mathrm{O}\right\}_{n}$}

In the presence of air, thiodiacetic acid $\left(\mathrm{tdaH}_{2}, 1.05 \mathrm{~g}, 6.99 \mathrm{mmol}\right)$ was dissolved in $\mathrm{H}_{2} \mathrm{O}$ $(5.0 \mathrm{~mL})$ and the $\mathrm{pH}$ was adjusted to 4.46 using $5 \mathrm{M} \mathrm{NaOH}$. In a separate vial, $\mathrm{BaCl}_{2}$ $(1.43 \mathrm{~g}, 6.87 \mathrm{mmol})$ was dissolved in $5.0 \mathrm{~mL} \mathrm{H}_{2} \mathrm{O}(\mathrm{pH}$ of the solution was 5.20). These two solutions were slightly cooled by holding the vials under tap water, and the contents were mixed in a beaker. After $\sim 5 \mathrm{~min}$ white needle-like crystals appeared, which were filtered and dried under vacuum overnight. Yield: $1.32 \mathrm{~g}(54 \%)$. Anal. Calcd for $\mathrm{Ba}\left[\mathrm{S}\left(\mathrm{CH}_{2} \mathrm{COO}\right)_{2}\left(\mathrm{H}_{2} \mathrm{O}\right)_{3}\right] \cdot 2 \mathrm{H}_{2} \mathrm{O}(\%)$ : C 12.8; $\mathrm{H}$ 3.76; $\mathrm{Ba} 36.6$. Found (\%): C 12.8; H 3.28; Ba 38.9. FT-IR (KBr, cm ${ }^{-1}$ ): 3500-3100 (s, br), 2957 (w), 2922 (w), 1561 (vs), 1388 (vs), 1242 (s), 1223 (s), 1190 (w), 1155 (m), 946 (w), 872 (m), 805 (w), 780 (w), 687 (m, br), 605 (w, br), 566 (w), 447 (w). ${ }^{1} \mathrm{H}$ NMR of 1 ( $\delta$, ppm; pD 5.03, $\left.\mathrm{D}_{2} \mathrm{O}\right): 3.30\left(\mathrm{CH}_{2}\right.$, s). ${ }^{13} \mathrm{C}$ NMR of $\mathbf{1}\left(\delta\right.$, ppm; pD 5.03, $\left.\mathrm{D}_{2} \mathrm{O}\right): 37.0\left(\mathrm{CH}_{2}, \mathrm{~s}\right)$ and $177.4(\mathrm{COO}, \mathrm{s}) .{ }^{1} \mathrm{H} \mathrm{NMR}$ of tda $\left(\delta, \mathrm{ppm} ; \mathrm{pD} 5.03, \mathrm{D}_{2} \mathrm{O}\right): 3.31\left(\mathrm{CH}_{2}, \mathrm{~s}\right) .{ }^{13} \mathrm{C} \mathrm{NMR}$ of tda $\left(\delta, \mathrm{ppm} ; \mathrm{pD} 5.03, \mathrm{D}_{2} \mathrm{O}\right)$ : $36.9\left(\underline{\mathrm{CH}}_{2}, \mathrm{~s}\right), 177.5$ (ㄷO, s). 
Table 1. Crystal data and structure refinement for $\left\{\mathrm{Ba}\left[\mathrm{S}\left(\mathrm{CH}_{2} \mathrm{COO}\right)_{2}\right.\right.$ $\left.\left.\left(\mathrm{H}_{2} \mathrm{O}\right)_{3}\right] \cdot 2 \mathrm{H}_{2} \mathrm{O}\right\}_{n}(\mathbf{1})$.

\begin{tabular}{|c|c|}
\hline Parameters & 1 \\
\hline Empirical formula & $\mathrm{C}_{4} \mathrm{H}_{14} \mathrm{BaO}_{9} \mathrm{~S}$ \\
\hline Formula weight & 375.55 \\
\hline Temperature (K) & $100(2)$ \\
\hline Wavelength $(\mathrm{Mo}-\mathrm{K} \alpha)(\AA)$ & 0.71073 \\
\hline Crystal system & Monoclinic \\
\hline Space group & $P 2_{1} / c$ \\
\hline Crystal dimensions $\left(\mathrm{mm}^{3}\right)$ & $0.56 \times 0.25 \times 0.20$ \\
\hline \multicolumn{2}{|l|}{ Unit cell dimensions $\left(\AA,^{\circ}\right)$} \\
\hline$a$ & $13.069(4)$ \\
\hline$b$ & $7.350(2)$ \\
\hline$c$ & $12.932(4)$ \\
\hline$\alpha$ & 90.000 \\
\hline$\beta$ & $115.368(5)$ \\
\hline$\gamma$ & 90.000 \\
\hline$V\left(\AA^{3}\right), Z$ & $1122.3(6), 4$ \\
\hline$D_{\text {Calcd }}\left(\mathrm{g} \mathrm{cm}^{-3}\right)$ & 2.223 \\
\hline$\mu\left(\mathrm{mm}^{-1}\right)$ & 3.753 \\
\hline$F(000)$ & 728 \\
\hline Unique reflections, $R_{\text {int }}$, parameters & $1990,0.0203,176$ \\
\hline Maximum, minimum absorption correction & $0.52,0.23$ \\
\hline$R_{1}^{\mathrm{a}}, w R_{2}^{\mathrm{b}}\left[F^{2}>2 \sigma\left(F^{2}\right)\right]$ & $0.0141,0.0360$ \\
\hline Final $\Delta \rho\left(\mathrm{e} \AA^{-3}\right)$ & $0.575,-0.656$ \\
\hline
\end{tabular}

\subsection{X-ray crystallography}

X-ray crystallography was performed by mounting each crystal onto a thin glass fiber from a pool of Fluorolube ${ }^{\mathrm{TM}}$ and immediately placing it under a liquid $\mathrm{N}_{2}$-cooled $\mathrm{N}_{2}$ stream on a Bruker AXS diffractometer. The radiation used was graphitemonochromated Mo-K $\alpha$ radiation $(\lambda=0.7107 \AA)$. The lattice parameters were optimized from a least-squares calculation on carefully centered reflections. Lattice determination, data collection, structure refinement, scaling, and data reduction were carried out using APEX2 version 1.0-27 software package. The structure was solved using direct methods, yielding $\mathrm{Ba}$, along with a number of the $\mathrm{S}, \mathrm{O}$, and $\mathrm{C}$ atoms. Subsequent Fourier synthesis yielded the remaining atom positions. The hydrogens were fixed in the positions of ideal geometry and refined within the XSHELL software. The idealized hydrogens had their isotropic temperature factors fixed at 1.2 or 1.5 times the equivalent isotropic $U$ of the carbons to which they were bonded. The final refinement of each compound included anisotropic thermal parameters on all nonhydrogen atoms. Crystal data and structure refinement parameters for $\mathbf{1}$ are listed in table 1. Selected interatomic distances and bond angles are listed in table 2.

\section{Results and discussion}

Upon addition of 1.02 mol-equivalents of tda to an aqueous solution of $\mathrm{BaCl}_{2}$, colorless needle-like crystals of $\left\{\mathrm{Ba}\left[\mathrm{S}\left(\mathrm{CH}_{2} \mathrm{COO}\right)_{2}\left(\mathrm{H}_{2} \mathrm{O}\right)_{3}\right] \cdot 2 \mathrm{H}_{2} \mathrm{O}\right\}_{n}$ (1) were obtained 
Table 2. Selected bond lengths $(\AA)$ and angles $\left(^{\circ}\right)$ for $\mathbf{1}$.

\begin{tabular}{lclr}
\hline $\mathrm{Ba}(1)-\mathrm{O}(1)$ & $2.7502(16)$ & $\mathrm{O}(4)-\mathrm{Ba}(1)-\mathrm{O}(5)$ & $65.77(5)$ \\
$\mathrm{Ba}(1)-\mathrm{O}(2)$ & $2.7272(17)$ & $\mathrm{O}(1)-\mathrm{Ba}(1)-\mathrm{O}(5)$ & $68.10(4)$ \\
$\mathrm{Ba}(1)-\mathrm{O}(1)^{\# 1}$ & $2.9349(16)$ & $\mathrm{O}(6)-\mathrm{Ba}(1)-\mathrm{O}(5)$ & $136.00(5)$ \\
$\mathrm{Ba}(1)-\mathrm{O}(2)^{\# 1}$ & $2.8375(16)$ & $\mathrm{O}(2)-\mathrm{Ba}(1)-\mathrm{O}(7)$ & $90.90(5)$ \\
$\mathrm{Ba}(1)-\mathrm{O}(4)$ & $2.7490(18)$ & $\mathrm{O}(4)-\mathrm{Ba}(1)-\mathrm{O}(7)$ & $71.66(5)$ \\
$\mathrm{Ba}(1)-\mathrm{O}(5)$ & $2.8978(18)$ & $\mathrm{O}(1)-\mathrm{Ba}(1)-\mathrm{O}(7)$ & $113.55(5)$ \\
$\mathrm{Ba}(1)-\mathrm{O}(6)$ & $2.8361(17)$ & $\mathrm{O}(6)-\mathrm{Ba}(1)-\mathrm{O}(7)$ & $78.92(5)$ \\
$\mathrm{Ba}(1)-\mathrm{O}(7)$ & $3.026(2)$ & $\mathrm{O}(5)-\mathrm{Ba}(1)-\mathrm{O}(7)$ & $136.43(5)$ \\
$\mathrm{Ba}(1)-\mathrm{S}(1)$ & $3.6487(9)$ & $\mathrm{O}(4)-\mathrm{Ba}(1)-\mathrm{S}(1)$ & $54.60(3)$ \\
$\mathrm{S}(1)-\mathrm{C}(2)$ & $1.799(2)$ & $\mathrm{O}(1)-\mathrm{Ba}(1)-\mathrm{S}(1)$ & $54.24(4)$ \\
$\mathrm{S}(1)-\mathrm{C}(3)$ & $1.812(2)$ & $\mathrm{O}(6)-\mathrm{Ba}(1)-\mathrm{S}(1)$ & $73.52(4)$ \\
$\mathrm{O}(1)-\mathrm{C}(1)$ & $1.253(3)$ & $\mathrm{O}(5)-\mathrm{Ba}(1)-\mathrm{S}(1)$ & $99.92(4)$ \\
$\mathrm{Ba}(1)-\mathrm{Ba}(1)^{\# 2}$ & $4.7357(11)$ & $\mathrm{O}(7)-\mathrm{Ba}(1)-\mathrm{S}(1)$ & $60.28(4)$ \\
$\mathrm{O}(2)^{\# 3}-\mathrm{Ba}(1)-\mathrm{O}(4)$ & $77.72(4)$ & $\mathrm{O}(2)^{\# 3}-\mathrm{Ba}(1)-\mathrm{O}(6)$ & $145.60(5)$ \\
$\mathrm{O}(2)^{\# 3}-\mathrm{Ba}(1)-\mathrm{O}(1)$ & $139.26(5)$ & $\mathrm{O}(4)-\mathrm{Ba}(1)-\mathrm{O}(6)$ & $127.84(5)$ \\
$\mathrm{O}(4)-\mathrm{Ba}(1)-\mathrm{O}(1)$ & $79.86(4)$ & $\mathrm{O}(2)^{\# 3}-\mathrm{Ba}(1)-\mathrm{O}(5)$ & $71.76(5)$ \\
\hline
\end{tabular}

Symmetry transformations used to generate equivalent atoms: ${ }^{\# 1}-x+2, y-1 / 2,-z+3 / 2 ;{ }^{\# 2}-x+2$, $y+1 / 2,-z+3 / 2 ;{ }^{\# 3} x, y-1, z$.

Table 3. Wavenumbers $\left(v, \mathrm{~cm}^{-1}\right)$ and band assignments for the FT-IR spectra of $\mathrm{tdaH}_{2}$ and its metal complexes.

\begin{tabular}{|c|c|c|c|c|c|c|c|c|c|c|}
\hline $1^{\mathrm{a}}$ & $2[7]$ & 3 [7] & $4[13]$ & $5[17]$ & 6 [9] & 7 [16] & $8[5]$ & $\begin{array}{l}\text { Assignments } \\
\text { for 1-8 }\end{array}$ & $9[18]$ & $\begin{array}{l}\text { Assignments } \\
\text { for } 9\end{array}$ \\
\hline 2957 & NR & NR & NR & 2986 & NR & 2981 & NR & $v_{\mathrm{as}}\left(\mathrm{CH}_{2}\right)$ & 2913 & $v_{\mathrm{s}}\left(\mathrm{CH}_{2}\right)$ \\
\hline 2922 & NR & NR & NR & 2931 & NR & 2928 & NR & $v_{\mathrm{s}}\left(\mathrm{CH}_{2}\right)$ & 2945 & $v_{\mathrm{as}}\left(\mathrm{CH}_{2}\right)$ \\
\hline 1561 & 1604 & 1565 & 1589 & 1567 & 1587 & 1590 & 1589 & $v_{\mathrm{as}}(\mathrm{COO}-)$ & 1700 & $v(\mathrm{C}=\mathrm{O})$ \\
\hline 1388 & NR & NR & 1399 & 1382 & NR & 1382 & 1399 & $v_{\mathrm{s}}(\mathrm{COO}-)$ & 1390 & $\omega\left(\mathrm{CH}_{2}\right)$ \\
\hline 687 & NR & NR & NR & NR & 717 & 713 & NR & $v(\mathrm{C}-\mathrm{S})$ & 790 & $v(\mathrm{C}-\mathrm{S})$ \\
\hline 447 & NR & NR & NR & NR & NR & NR & NR & $\delta(\mathrm{CCS})$ & 441 & $\delta(\mathrm{CCS})$ \\
\hline
\end{tabular}

in $\sim 54 \%$ yield. Complex 1 is soluble in warm water and is stable in air. The experimentally determined percentages of $\mathrm{C}$ and $\mathrm{H}$ agree well with the calculated values for $\mathbf{1}$. However, the experimentally determined percentage of S $(4.95 \%)$ is considerably lower than that expected for $\mathbf{1}(8.54 \%)$. It has been reported previously for other metal-tda complexes that $\mathrm{S}$ can be released as gaseous $\mathrm{SO}_{2}$ prior to analysis [16].

Complex 1 was further characterized by ${ }^{1} \mathrm{H}$ and ${ }^{13} \mathrm{C}$ NMR spectroscopy, mass spectrometry, FT-IR and TGA. Identical ${ }^{1} \mathrm{H}$ NMR spectra were obtained $\left(\mathrm{D}_{2} \mathrm{O}\right.$, $\mathrm{pD}$ 5.03) for $\mathbf{1}$ and free tda, suggesting that the self-assembly of $\mathbf{1}$ is a solid-state phenomenon only (a singlet at $3.31 \pm 0.01 \mathrm{ppm}, \mathrm{CH}_{2}$ ). The ${ }^{13} \mathrm{C}$ NMR spectra for $\mathbf{1}$ and tda were also identical under the same conditions $\left(\mathrm{D}_{2} \mathrm{O}, \mathrm{pD} 5.03 ; 36.9 \pm 0.1\left(\mathrm{CH}_{2}, \mathrm{~s}\right)\right.$ and $177.4 \pm 0.1 \mathrm{ppm}(\underline{\mathrm{COO}}, \mathrm{s}))$. No significant peaks were observed in the ES-MS spectrum of 1 .

There are numerous reports concerning infrared (IR) spectral assignments of metaltda complexes $[5,8,9,13,16,17]$. In table 3 the wavenumbers of characteristic IR bands for $\mathbf{1}$ are compared with those obtained for other metal-tda complexes. The FT-IR 
spectrum of 1 (figure S1, Supplementary material) shows a very broad, strong band at $3500-3000 \mathrm{~cm}^{-1}$, corresponding to the stretching vibration modes for coordinated water of 1. Two weak bands at 2957 and $2922 \mathrm{~cm}^{-1}$ are assigned as $v_{\text {as }}\left(\mathrm{CH}_{2}\right)$ and $v_{\mathrm{s}}\left(\mathrm{CH}_{2}\right)$, respectively. Intense bands at 1561 and $1388 \mathrm{~cm}^{-1}$ correspond to $v_{\text {as }}\left(\mathrm{COO}^{-}\right)$ and $v_{\mathrm{s}}\left(\mathrm{COO}^{-}\right)$, respectively. Finally, bands at 687 and $447 \mathrm{~cm}^{-1}$ can be assigned as $\nu(\mathrm{C}-\mathrm{S})$ and $\delta(\mathrm{CCS})$, respectively. The corresponding bands for $\mathrm{tdaH}_{2}$ itself are also given in table 3 [18]. The values of $v_{\mathrm{as}}\left(\mathrm{COO}^{-}\right)$and $v_{\mathrm{s}}\left(\mathrm{COO}^{-}\right)$observed for $\mathbf{1}$ are similar to those obtained for other metal-tda complexes and are significantly lower in wavenumber than the $\mathrm{C}=\mathrm{O}$ bond stretch for tdaH $\mathrm{H}_{2}\left(\nu(\mathrm{C}=\mathrm{O})=1700 \mathrm{~cm}^{-1}\right)$, as expected due to a weakening of this bond upon deprotonation of the carboxylic acid. Comparison of the $v_{\text {as }}\left(\mathrm{COO}^{-}\right)$values for the tda polymers of $\mathrm{Ca}^{2+}, \mathrm{Sr}^{2+}$, and $\mathrm{Ba}^{2+}$ shows a decreasing trend from $\mathrm{Ca}^{2+}, \mathrm{Sr}^{2+}$, to $\mathrm{Ba}^{2+}\left(1604,1565\right.$, and $1561 \mathrm{~cm}^{-1}$, respectively, table 3 ). This may be attributed to the fact that with increasing size of the metal cation $\left(\mathrm{Ca}^{2+}<\mathrm{Sr}^{2+}<\mathrm{Ba}^{2+}\right)$, the metal binds more weakly to the $\mathrm{COO}^{-}$group of the tda in the complexes. This is reflected in the $\mathrm{M}-\mathrm{O}_{\text {carboxylate }}$ bond distances (see below).

The thermal decomposition of $\mathbf{1}$ under a flow of nitrogen was investigated by TGA. The thermogram (figure S2, Supplementary material) clearly shows that more than one species is lost in the first step $\left(40-150^{\circ} \mathrm{C}\right.$, mass loss $\left.16.36 \%\right)$. Loss of the two water molecules of crystallization of $\mathbf{1}$ corresponds to a mass loss of $9.59 \%$. Further experiments are required to unambiguously identify the other species lost; however, the remaining mass loss can be attributed to $\mathrm{CO}(7.46 \%)$. The mass loss in the second step $\left(300-500^{\circ} \mathrm{C}, 24.39 \%\right)$ can be assigned to the loss of three bound water molecules $(14.38 \%)$ and one $\mathrm{CO}_{2}(11.72 \%)$. Release of $\mathrm{CO}$ and $\mathrm{CO}_{2}$ has been previously observed for other metal-tda complexes [16, 17].

\subsection{Structural characterization of 1 by $X$-ray diffraction}

The complex crystallized in the monoclinic space group $P 2_{1} / c$ with four molecules per unit cell. The thermal ellipsoid plot of $\mathbf{1}$ (figure 1) shows that each $\mathrm{Ba}^{2+}$ is indirectly coordinated to three adjacent $\mathrm{Ba}^{2+}$ centers through bridging tda ligands $(\mathrm{Ba}(1)-\mathrm{Ba}(1 \mathrm{~A})$ 4.736 $\AA$, $\mathrm{Ba}(1)-\mathrm{Ba}(1 \mathrm{~B}) 6.474 \AA$, and $\mathrm{Ba}(1)-\mathrm{Ba}(1 \mathrm{C}) 7.350 \AA$ ). Similar $\mathrm{Ba}-\mathrm{Ba}$ distances (4.374-7.034 $\mathrm{A}$ ) were observed for a 2-D $\mathrm{Ba}^{2+} /$ oda coordination polymer, $\left[\mathrm{Ba}(\text { oda }) \cdot \mathrm{H}_{2} \mathrm{O}\right]_{n}$ [10]. The coordination environment around each $\mathrm{Ba}^{2+}$ in $\mathbf{1}$ is identical and is illustrated in figure 2. Each $\mathrm{Ba}^{2+}$ is surrounded by 10 donors: six carboxylate oxygens from four tda ligands, a tda sulfur, and three oxygens from water. The $\mathrm{Ba}^{2+}$ coordination geometry is distorted, rather than being an ordered polyhedral geometry. In $\left[\mathrm{Ba}(\text { oda }) \cdot \mathrm{H}_{2} \mathrm{O}\right]_{n}$, each $\mathrm{Ba}^{2+}$ was nine-coordinate with a distorted monocapped square antiprismic geometry [10].

The tda ligand has four modes of coordination (Modes I-IV, scheme 1). In Mode I tda binds via two oxygens of the two carboxylates and the sulfur to the $\mathrm{Ba}^{2+}$ center. The $\mathrm{Ba}-\mathrm{S}$ bond distance is $3.649 \AA, 0.13 \AA$ longer than other reported polymeric thioether complexes of $\mathrm{Ba}^{2+}$ (CSD: three hits) in which the $\mathrm{Ba}-\mathrm{S}$ bond distances are in the 3.338-3.516 $\AA$ range [19-21], and significantly longer than monomeric thioether complexes of $\mathrm{Ba}^{2+}$ (CSD: three hits) in which the $\mathrm{Ba}-\mathrm{S}$ bond distances are in the 3.014$3.290 \AA$ range [22-24]. The two $\mathrm{Ba}-\mathrm{O}_{\text {carboxylate }}$ bond distances in this mode are identical $(2.750 \AA$ A). In Mode II, a single oxygen of the carboxylate bridges two adjacent 


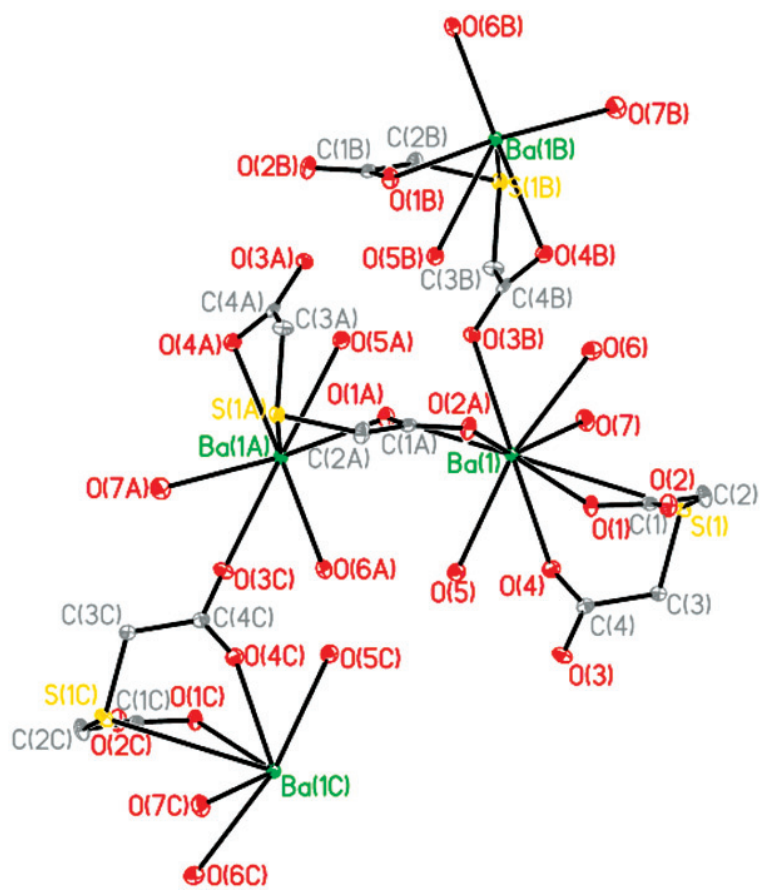

Figure 1. Thermal ellipsoid plot $(30 \%)$ of the partial linkage motif in $\left\{\mathrm{Ba}\left[\mathrm{S}\left(\mathrm{CH}_{2} \mathrm{COO}\right)_{2}\left(\mathrm{H}_{2} \mathrm{O}\right)_{3}\right] \cdot 2 \mathrm{H}_{2} \mathrm{O}\right\}_{n}(\mathbf{1})$. $\mathrm{H}$ atoms are omitted for clarity.

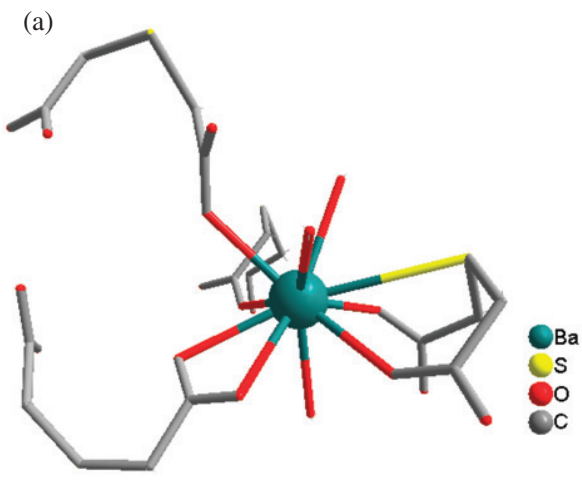

(b)<smiles>OC(O)CSCC(O)O[Ge]1(O)OC(CSCC(O)O)OC(CSCC(O)O)OC2(O)OCCSC21O</smiles><smiles>OC(O)CSCC(O)O</smiles>

Figure 2. (a) Ball and stick diagram of $\mathbf{1}$ showing the coordination environment around each $\mathrm{Ba}^{2+}$ center. $\mathrm{H}$ atoms are omitted for clarity. (b) Schematic diagram of the coordination environment around each Ba center.

Ba centers in the same layer, with $\mathrm{Ba}-\mathrm{O}_{\text {carboxylate }}$ bond distances of 2.727 and $2.838 \AA$. In coordination Mode III, a carboxylate group bridges two $\mathrm{Ba}^{2+}$ centers in adjacent layers with $\mathrm{Ba}-\mathrm{O}_{\text {carboxylate }}$ bond distances of 2.749 and $2.752 \AA$. Finally, in Mode IV, a single oxygen of carboxylate is coordinated to $\mathrm{Ba}^{2+}$, with a $\mathrm{Ba}-\mathrm{O}_{\text {carboxylate }}$ bond

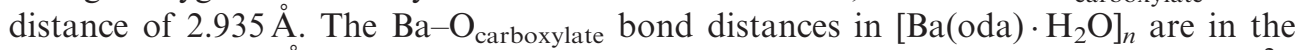
range 2.747-3.311 $\AA$, similar to that of 1 . The three other coordination sites of the $\mathrm{Ba}^{2+}$ 
<smiles>O=C1CS[R8]2OC(=O)C1O2</smiles>

Mode I<smiles>O=C(O)CSCC(=O)OCBr</smiles>

Mode II<smiles>O=C(O)CSCC(=O)OCc1ccccc1</smiles>

Mode III<smiles>O=C(O)CSCC(O)O[Ga]</smiles>

Mode IV

Scheme 1. Modes of coordination of tda to $\mathrm{Ba}^{2+}$ in $\mathbf{1}$.

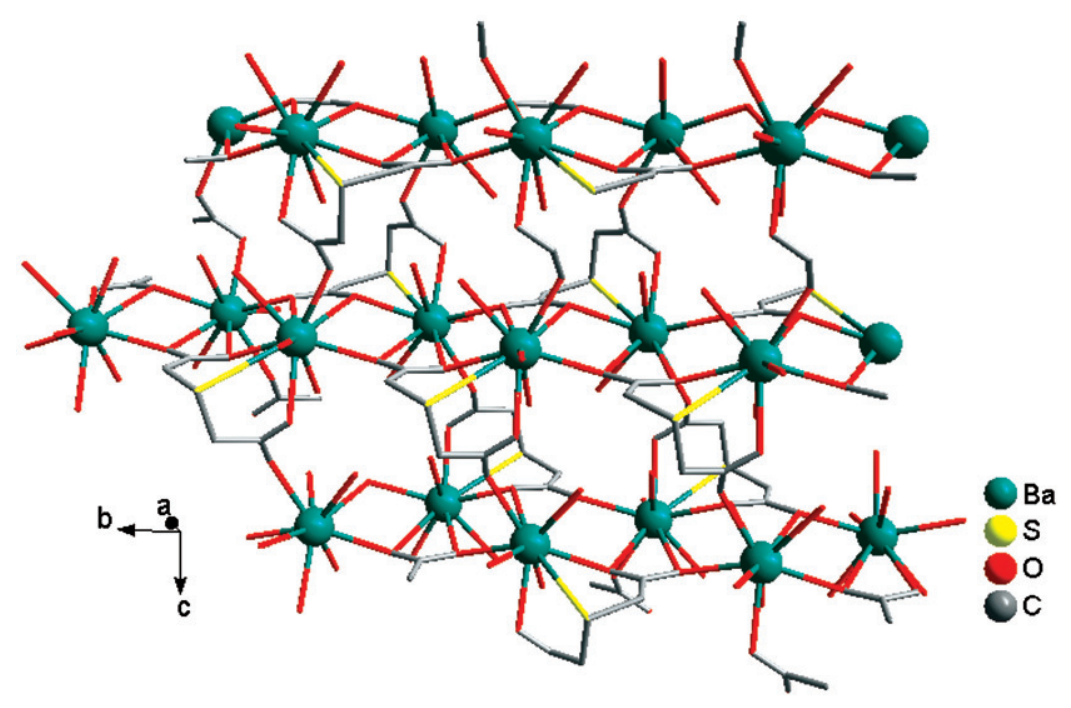

Figure 3. Structure of $\mathbf{1}$ showing the Ba-tda network layers parallel to the $b c$-plane (along the $a$-axis).

in the complex are occupied by three oxygens from waters, with average $\mathrm{Ba}-\mathrm{O}_{\text {(water) }}$ distance being $2.921 \AA$. This $\mathrm{Ba}-\mathrm{O}_{\text {(water) }}$ distance is $0.13 \AA$, shorter than that observed in $\left[\mathrm{Ba}(\text { oda }) \cdot \mathrm{H}_{2} \mathrm{O}\right]_{n}(3.047 \AA)[10]$.

Overall a 2-D layered oligonuclear network is generated in $\mathbf{1}$ (figure 3), with channels of $\sim 2.3 \AA$ diameter formed between the Ba layers along the $b c$-plane. These channels are wide enough to accommodate an interstitial water layer (figure 4). Ba centers in adjacent layers are bridged by tda ligands, and the channels are lined with the tda sulfurs and $\mathrm{H}_{2} \mathrm{O}$ ligands from the $\mathrm{Ba}^{2+}$ centers, which form hydrogen bonds with the interstitial waters.

2-D-coordination polymers of $\mathrm{Ca}^{2+}$ and $\mathrm{Sr}^{2+}$ incorporating the tda ligand have been reported with formulae $\left[\mathrm{Ca}^{2+}(\mathrm{tda})\left(\mathrm{H}_{2} \mathrm{O}\right)\right]_{n}$ and $\left[\mathrm{Sr}^{2+}(\mathrm{tda})\right]_{n}$ [7]. Interestingly, all four binding modes of the tda ligand observed in $\mathbf{1}$ are also found in the $\mathrm{Ca}^{2+}$ complex. However, due to the smaller van der Waals radius of $\mathrm{Ca}^{2+}$ compared with $\mathrm{Ba}^{2+}$, the $\mathrm{Ca}^{2+}$ center of $\left[\mathrm{Ca}^{2+}(\mathrm{tda})\left(\mathrm{H}_{2} \mathrm{O}\right)\right]_{n}$ is instead a distorted dodecahedron, with seven sites occupied by the four tda ligands (six $\mathrm{O}$ and one $\mathrm{S}$ ) and the remaining site occupied by a water. Unlike $\mathbf{1}$, the aqua ligand bridges $\mathrm{Ca}^{2+}$ centers in adjacent layers, hence there 


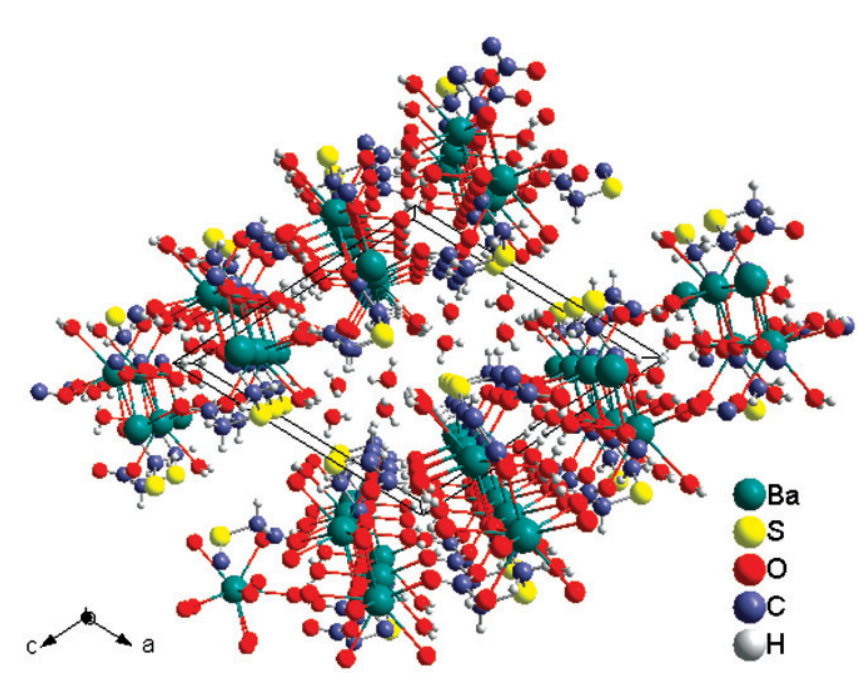

Figure 4. View of the framework in $\mathbf{1}$ along the $b$-axis. The lattice water molecules are shown inside the channels between the layers.

are no channels formed between the layers wide enough to accommodate a layer of solvent molecules $(0.96 \AA$ gap between the layers).

In $\left[\mathrm{Sr}^{2+}(\mathrm{tda})\right]_{n}$ the $\mathrm{Sr}^{2+}$ center is eight-coordinate. Donor atoms from tda $(\mathrm{O}, \mathrm{S})$ occupy the first coordination sphere of $\mathrm{Sr}^{2+}$ and the additional binding modes of tda are also observed which were not found in $\mathbf{1}$ nor $\left[\mathrm{Ca}^{2+}(\mathrm{tda})\left(\mathrm{H}_{2} \mathrm{O}\right)\right]_{n}$. The $\mathrm{Sr}^{2+}$ centers in adjacent layers are bridged by tda and once again a solvent layer is not observed $(0.77 \AA$ channel between the layers). The $\mathrm{M}^{2+}-\mathrm{S}$ bond distances in the $\mathrm{Ca}^{2+}(3.079 \AA)$ and $\mathrm{Sr}^{2+}$ $(3.406 \AA)$ polymers are shorter than in $1(3.649 \AA)$, consistent with the larger size of $\mathrm{Ba}^{2+}$ compared with $\mathrm{Ca}^{2+}$ and $\mathrm{Sr}^{2+}$. The $\mathrm{M}-\mathrm{O}_{\text {carboxylate }}$ bond distances in the latter two polymers are in the 2.391-2.575 $\AA$ range and are once again shorter than those observed in $1(2.727-2.935 \AA)$.

Finally, it should be noted that not all metal-tda complexes are polymeric. Indeed, $\mathrm{Mg}, \mathrm{Co}, \mathrm{Ni}$, and $\mathrm{Zn}$ form monomeric tda complexes of the general formula $\left[\mathrm{M}^{n+}(\mathrm{tda})\left(\mathrm{H}_{2} \mathrm{O}\right)_{3}\right] \cdot n \mathrm{H}_{2} \mathrm{O}[5,7,9,16,25]$. In these complexes the tda binds in the typical fac $(\mathrm{O}, \mathrm{O}, \mathrm{S})$ coordination mode to the metal. The $\mathrm{M}-\mathrm{O}_{\text {carboxylate }}$ bond distances in these complexes are in the range 2.040-2.060 $\mathrm{A}$ and the $\mathrm{M}-\mathrm{S}$ bond distances are in the range of $2.415-2.729 \AA$, notably shorter than the $\mathrm{M}-\mathrm{O}_{\text {carboxylate }}$ and $\mathrm{M}-\mathrm{S}$ bond distances in 1 and in $\left[\mathrm{Ca}^{2+}(\mathrm{tda})\left(\mathrm{H}_{2} \mathrm{O}\right)\right]_{n}$ and $\left[\mathrm{Sr}^{2+}(\mathrm{tda})\right]_{n}$.

\section{Summary}

A 2-D coordination polymer of $\mathrm{Ba}^{2+},\left\{\mathrm{Ba}\left[\mathrm{S}\left(\mathrm{CH}_{2} \mathrm{COO}\right)_{2}\left(\mathrm{H}_{2} \mathrm{O}\right)_{3}\right] \cdot 2 \mathrm{H}_{2} \mathrm{O}\right\}_{n}(\mathbf{1})$, has been crystallized from aqueous solution in good yield. Compound $\mathbf{1}$ has been characterized by X-ray diffraction in addition to IR spectroscopy and TGA. In $\mathbf{1}$, the $\mathrm{Ba}^{2+}$ centers are ten-coordinate and are bridged by tda. Four distinct binding modes of the tda ligand are observed. Unlike $\left[\mathrm{Ca}^{2+}(\mathrm{tda})\left(\mathrm{H}_{2} \mathrm{O}\right)\right]_{n}$, the larger radius of $\mathrm{Ba}^{2+}$ results in the 
formation of a channel wide enough to accommodate $\mathrm{H}_{2} \mathrm{O}$ molecules between the $\mathrm{Ba}^{2+}$ / tda layers. ${ }^{1} \mathrm{H}$ and ${ }^{13} \mathrm{C}$ NMR spectroscopic data suggest that $\mathbf{1}$ does not spontaneously form in aqueous solution itself.

\section{Supplementary material}

Crystallographic data (excluding structure factors) for the structures in this article have been deposited with the Cambridge Crystallographic Data Centre as supplementary publication No. CCDC 761033. Copies of the data can be obtained free of charge on application to CCDC, 12 Union Road, Cambridge CB2 1EZ, UK (Fax: +44(0)1223-336033 or E-mail: deposit@ccdc.cam.ac.uk). The FT-IR spectrum and the thermogram of $\mathbf{1}$ are given in the Supplementary material and are available from the journal website.

\section{Acknowledgments}

We thank Ms Joanna Gorka, Kent State University, for assistance with the TGA measurements. This research was supported by the Ohio Board of Regents (Nicola E. Brasch) and the National Science Foundation (CHE-0848397, Nicola E. Brasch).

\section{References}

[1] R.J. Kuppler, D.J. Timmons, Q.-R. Fang, J.-R. Li, T.A. Makal, M.D. Young, D. Yuan, D. Zhao, W. Zhuang, H.-C. Zhou. Coord. Chem. Rev., 253, 3042 (2009).

[2] W. Mori, S. Takamizawa, C.N. Kato, T. Ohmura, T. Sato. Microporous Mesoporous Mater., 73, 31 (2004).

[3] Y.D. Lampeka, L.V. Tsymbal. Theor. Exp. Chem., 40, 345 (2004).

[4] B.-H. Ye, M.-L. Tong, X.-M. Chen. Coord. Chem. Rev., 249, 545 (2005).

[5] A. Grirrane, A. Pastor, E. Álvarez, C. Mealli, A. Ienco, D. Masi, A. Galindo. Inorg. Chem. Commun., 8, $463(2005)$.

[6] A. Grirrane, A. Pastor, A. Galindo, D. del Río, A. Orlandini, C. Mealli, A. Ienco, A. Caneschi, J. Farnández Sanz. Angew. Chem. Int. Ed., 44, 3429 (2005).

[7] A. Grirrane, A. Pastor, E. Álvarez, R. Moyano, A. Galindo. Inorg. Chem. Commun., 10, 1125 (2007).

[8] A. Grirrane, A. Pastor, E. Álvarez, C. Mealli, A. Ienco, A. Galindo. Inorg. Chem. Commun., 9, 160 (2006).

[9] A. Grirrane, A. Pastor, E. Álvarez, A. Galindo. Inorg. Chem. Commun., 8, 453 (2005).

[10] R. Baggio, M.T. Garland, G. Leyva, M. Perec, G. Polla. Inorg. Chim. Acta, 357, 2185 (2004).

[11] R. Baggio, M.T. Garland, M. Perec, D. Vega. Inorg. Chem., 35, 2396 (1996).

[12] C. Kremer, J. Torres, S. Domínguez. J. Mol. Struct., 879, 130 (2008).

[13] A. Grirrane, A. Pastor, E. Álvarez, C. Mealli, A. Ienco, P. Rosa, A. Galindo. Eur. J. Inorg. Chem., 3543 (2007).

[14] T.J. Meyer, J.A. McCleverty (Eds.). Comprehensive Coordination Chemistry, p. 22, Elsevier, New York (2004).

[15] T.J. Meyer, J.A. McCleverty (Eds.). Comprehensive Coordination Chemistry, p. 7, Elsevier, New York (1987).

[16] C. Alarcón-Payer, T. Pivetta, D. Choquesillo-Lazarte, J.M. González-Pérez, G. Crisponi, A. Castiñeiras, J. Niclós-Gutiérrez. Inorg. Chem. Commun., 7, 1277 (2004).

[17] C. Alarcón-Payer, T. Pivetta, D. Choquesillo-Lazarte, J.M. González-Pérez, G. Crisponi, A. Castiñeiras, J. Niclós-Gutiérrez. Inorg. Chim. Acta, 358, 1918 (2005). 
[18] H. Ramsis, E. Perez-Ruiz, J. Roger, J.L. Delarbre, L. Maury. J. Raman Spectrosc., 27, 637 (1996).

[19] J. Beck, Y. Ben-Amer. Z. Anorg. Allg. Chem., 634, 1522 (2008).

[20] K. Henke, D.A. Atwood. Inorg. Chem., 37, 224 (1998).

[21] T. Rottgers, W.S. Sheldrick. Z. Anorg. Allg. Chem., 627, 1976 (2001).

[22] G. Weber. Inorg. Chim. Acta, 58, 27 (1982).

[23] S. Chadwick, U. Englich, K. Ruhlandt-Senge. Chem. Commun., 2149 (1998).

[24] K. Ruhlandt-Senge, U. Englich. Chem.-Eur. J., 6, 4063 (2000).

[25] M.G.B. Drew. J. Chem. Soc., Dalton Trans., 144 (1975). 